\title{
27. PLANKTONIC FORAMINIFERAL EVENTS AND STABLE ISOTOPE RECORDS IN THE UPPER MIOCENE, SITE 6541
}

\author{
Georgette Glaçon, ${ }^{2}$ Colette Vergnaud Grazzini, ${ }^{3}$ Silvia Iaccarino, ${ }^{4}$ Jean-Pierre Rehault, ${ }^{5}$ Auran Randrianasolo, ${ }^{2}$ \\ Javier Francisco Sierro, ${ }^{6}$ Philip Weaver, ${ }^{7}$ James Channell, ${ }^{8}$ Masayuki Torii, ${ }^{9}$ and Teresa Hawthorne ${ }^{8}$
}

\begin{abstract}
The late Miocene sediments of the Tyrrhenian ODP Site 654 encompass a deepening sequence which begins with glauconite shallow water sands followed by a rapid transition to deep water sediments and culminates with dolomitic mudstones associated with Messinian evaporites. The sequence compares well with the so-called "Sahelian cycle" and with post-orogenic cycles recognized in peninsular Italy and Sicily. The studied interval, consisting of $55 \mathrm{~m}$ thick nannofossil oozes, belongs to the Globorotalia suterae subzone and lower part of the Globorotalia conomiozea Zone, indicating late Tortonian and early Messinian age, respectively. Biomagnetostratigraphic correlation assigns the Tortonian/ Messinian boundary an age of 6.44-6.45 Ma. In addition, six main events have been recognized, based on the range of keeled globorotaliids and coiling direction changes of keeled and unkeeled globorotaliids, which have been correlated to the geomagnetic time-scale. Comparison with North Atlantic sites and land sections of the Guadalquivir basin and northern Morocco provides good correlations with the events documented in these areas. In particular, Event IV, which predates the FO of Globorotalia conomiozea, may be used to recognize the Tortonian/Messinian boundary in extraMediterranean areas where G. conomiozea is missing. Variations in the distribution of different species of Globigerinoi$d e s$ are related to changes in the surficial marine environment. Although no clear trends can be recognized on the oxygen and carbon isotope records of Globigerinoides obliquus, the parallelism between the occurrence of low salinity species (G. sacculifer) and peaks of low $\delta^{18} \mathrm{O}$ values, as well as that of normal salinity species (G. obliquus) and peaks of high $\delta^{18} \mathrm{O}$ values, suggests strong local changes of environmental conditions. The high amplitude of the fluctuations of $\delta^{18} \mathrm{O}$ values suggests important variations in the salinity of the Tyrrhenian Sea, related to a rapidly changing water budget. The major feature of the carbon isotope record is a large decrease between 7.0 and $6.95 \mathrm{Ma}$, which therefore predates the 6.2 Ma global "carbon shift."
\end{abstract}

\section{INTRODUCTION}

The upper Miocene sequence drilled at Site $654\left(40^{\circ} 34.76^{\prime} \mathrm{N}\right.$, $10^{\circ} 41.80^{\prime} \mathrm{E}, 2217 \mathrm{~m}$ water depth) could be considered as a "text-book" example of a transgressive sequence. Shallow water sediments represented by marine glauconitic sands are followed by nannofossil oozes of deep water environment, as indicated also by benthic foraminiferal assemblages (Shipboard Scientific Party, 1987). The sequence is capped by dolomitic mudstones indicating reduced circulations and severe exchanges with the open ocean. The major aims of this study are: (1) to describe and discuss the grain-size distribution and to correlate it with biostratigraphic results; (2) to recognize the major paleontologic events and to compare them with those documented in Miocene land marine sections from the Mediterranean and Atlantic provinces; (3) to compare the latter events with the oxygen isotope stratigraphy; and (4) to compare the oxygen and carbon isotopic records at Site 654 with similar records of the open ocean well tied to the paleomagnetic time-scale, and to investigate the Mediterranean record of the global "carbon shift" of the late Miocene.

\footnotetext{
${ }^{1}$ Kastens, K. A., Mascle, J., et al., 1990. Proc. ODP, Sci. Results, 107: College Station, TX (Ocean Drilling Program).

${ }^{2}$ Laboratoire de Stratigraphie et de Paléoécologie, Université de Provence, Marseille, France.

${ }^{3}$ Laboratoire de Géologie Dynamique, Université Pierre et Marie Curie, Paris, France.

${ }^{4}$ Istituto di Geologia, Universita di Parma, Italy.

5 Laboratoire de Géodynamique sous-marine, Villefranche-sur-Mer, France.

6 Departamento de Paleontologia, Universidad de Salamanca, Spain.

7 Institute of Oceanographic Sciences, Godalming, Surrey, England.

8 Department of Geology, University of Florida, Gainesville, FL 32611.

9 Department of Geology and Mineralogy, Kyoto University, 606 Kyoto, Japan.
}

\section{METHODS}

The planktonic foraminifers of 114 samples have been analyzed semiquantitatively, and their distribution is plotted in the range chart of Figure 1. Eighty samples of $20 \mathrm{~cm}^{3}$ were dried for $6 \mathrm{hr}$ at $60^{\circ} \mathrm{C}$, weighted, and then washed through sieves of $500,200,125$, and $50 \mu \mathrm{m}$ mesh. The residues were dried and weighted. The values, reported per $100 \mathrm{~g}$ of original sample and displayed in Table 1 and Figure 2, have been used for the grain-size distribution except for samples at each 50$52 \mathrm{~cm}$ interval and the core catchers. Unfortunately, poor recovery, core deformation due to rotary drilling, strong burrowing, and irregular sampling severely hampered efforts to obtain highly precise results.

Oxygen and carbon isotope analyses have been performed on Globigerinoides quadrilobatus and Globigerinoides obliquus from 36 different levels. The analytic procedure has been described in Vergnaud Grazzini et al. (this volume). Paired analyses of both species suggest that $G$. quadrilobatus $\delta^{18} \mathrm{O}$ and $\delta^{13} \mathrm{C}$ values are higher by about $0.20 \%$ and $0.23 \%$, respectively, than those of $G$. obliquus. It was therefore possible to built a more complete record using data from $G$. obliquus and $\delta^{18} \mathrm{O}$ and $\delta^{13} \mathrm{C}$ values of $G$. quadrilobatus adjusted by $-0.20 \% 0$ and $-0.23 \%$, respectively. It is not yet possible to state precisely whether the different isotopic composition of both species depend on different seasonal depth habitat or other specific effects.

\section{LITHOLOGY AND GRAIN-SIZE DISTRIBUTION}

Five major units, numbered 2 to 6 , have been recognized within the Miocene sequence (Borsetti et al., this volume).

1. Unit $2,69.9 \mathrm{~m}$ thick (312.16-242.7 mbsf) is characterized by interbedded gypsum and carbonate layers.

2. Unit $3,36.3 \mathrm{~m}$ thick (348.9-312.6 mbsf) is characterized by dolomitic dark shales, suggesting an anoxic environment. Convolute laminations and microfaults have been observed. The first intervals of thin laminated dolomitic mudstone appear at the top of $654 \mathrm{~A}-40 \mathrm{R}$. In this unit (Section 1) planktonic foraminifers become very rare or are absent. 
Figure 1. Range chart of the planktonic foraminiferal species at Hole 654A. Note: most of the globorotaliids that have been distinguished might only be phenotypes, but their occurrence may have a paleoenvironmental significance. "Scituliform" Globorotalia (columns 5 and 6) encompass transitional morphotypes. Frequency of the species in the fraction larger than $125 \mu \mathrm{m}$ :

$$
\begin{aligned}
& A=\text { Abundant }-1 \text { out of } 2 \text { or } 3 \text { individuals is of the species } \\
& C=\text { Common }-1 \text { out of } 4-7 \text { individuals is of the species } \\
& F=\text { Few }-1 \text { out of } 8-30 \text { individuals is of the species } \\
& R=\text { Rare-less than } 1 \text { individual out of } 30 \text { is of the species }
\end{aligned}
$$

Note: Globigerina quinqueloba Natland is the dominant species in the fraction smaller than $125 \mu \mathrm{m}$; compared to that of other larger species, its abundances are always significantly higher.

Column:

1: sinistral Neogloboquadrina acostaensis (Blow)

2: dextral

3: sinistral Neogloboquadrina humerosa Takayanagi and Saito N. praehumosa Natori

4: dextral

5: sinistral Globorotalia "scituliform"

6: dextral

7: sinistral Globorotalia ventriosa Ogniben

8: dextral

9: sinistral Globorotalia suterae Catalano and Sprovieri

10: dextral

11: sinistral Globorotalia exserta Romeo

12: dextral

13: sinistral Globorotalia nicolae Catalano and Sprovieri

14: dextral

15: sinistral Globorotalia cibaoensis Bermudez

16: dextral

17: sinistral Globorotalia juanai Bermudez and Bolli G. praemargaritae Catalano and Sprovieri G. martinezi Perconig G. andalusiana Perconig

18: dextral

19: sinistral Globorotalia scitula (Brady)

20: dextral

21: sinistral Globorotalia saheliana Catalano and Sprovieri

22: dextral

23: sinistral Globorotalia sphericomiozea Walters G. saphoae Bizon and Bizon

24: dextral

25: sinistral Globorotalia conomiozea Kennett (Mediterranean form)

26: dextral

27: sinistral Globorotalia subconomiozea Bandy

28: dextral

29: sinistral Globorotalia mediterranean Catalano and Sprovieri

30: dextral

31: sinistral Globorotalia conoidea Walters

32: dextral

33: sinistral Globorotalia conoidea Walters

34: dextral

35: sinistral Globorotalia plesiotumida Blow and Banner G. merotumida Blow and Banner

36: dextral

37: sinistral Globorotalia limbata (Fomasini)

38: dextral

39: dextral Globorotalia menardii form 5 Tjalsma

40: sinistral Globorotalia menardii form 4 Tjalsma

41: Globigerina bulloides d'Orbigny

46: Globigerina decoraperta Takayanagi and Saito

47: Globigerina nepenthes Todd G. druyi Akers

48: Orbulina universa d'Orbigny

49: Dentoglobigerina altispira (Cushman and Jarvis)

50: Globigerinoides obliquus Bolli

51: Globigerinoides extremus Bolli

52: Globigerinoides quadrilobatus (d'Orbigny)

53: Globigerinoides trilobus (Reuss)

54: Globigerinoides bulloideus Crescenti

55: Globigerinoides ruber (d'Orbigny)

56: Globigerinoides sacculifer (Brady)
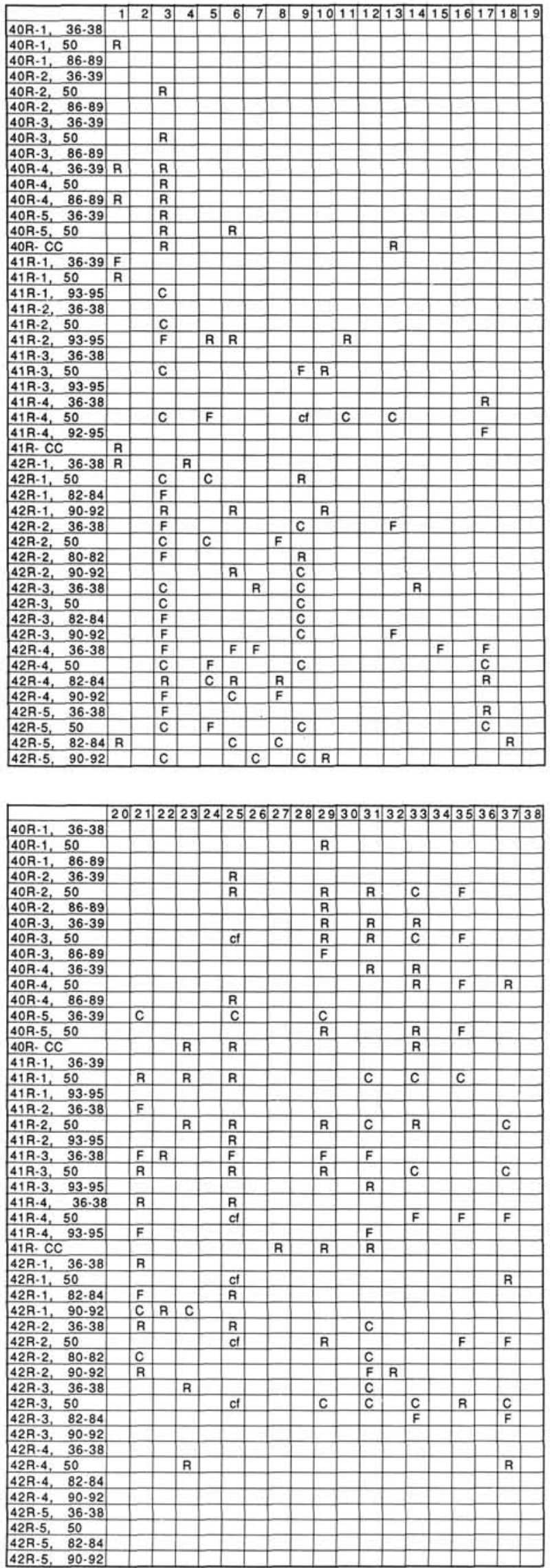

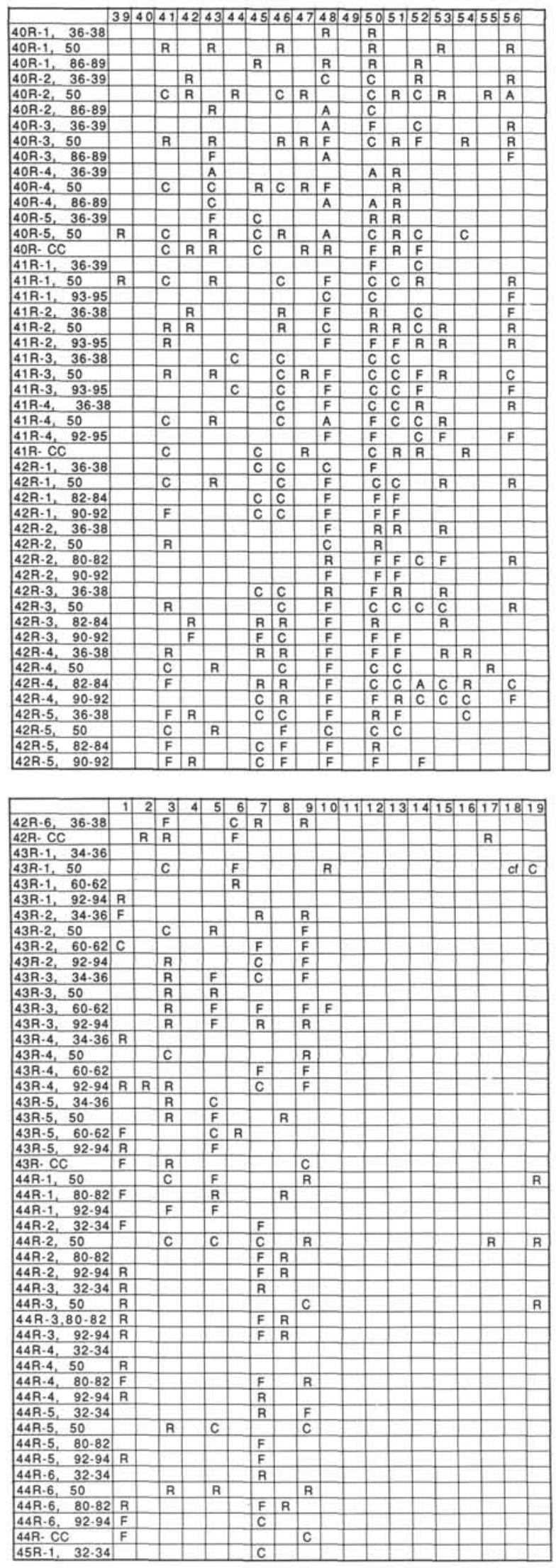

\begin{tabular}{|c|c|c|c|c|c|c|c|c|c|c|c|c|c|c|c|}
\hline & 202 & & 23. & 2425 & & & & & & & 34. & $\sqrt{35}$ & & 373 & \\
\hline$\frac{42 R-6, \quad 36-38}{42 R \cdot C C}$ & 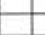 & & & & & & & & & & & & & & \\
\hline $43 \mathrm{~A}-1, \quad 34-36$ & & & & & & & & $\mathrm{~B}$ & & & & & & & \\
\hline $43 R-1,50$ & & & & & & & & $\mathrm{~A}$ & & & & & & A & $F$ \\
\hline $43 \mathrm{R}-1, \quad 60-62$ & & & & & & & & & & & & & & & \\
\hline $43 R-1, \quad 92-94$ & & & & & & & & & & & & & R & & \\
\hline $\begin{array}{ll}43 \mathrm{~A}-2, & 34-36 \\
43 \mathrm{~B}-2 & 50\end{array}$ & & & & & & & & & & & & & & & \\
\hline $\begin{array}{l}43 \mathrm{R}-2,50 \\
43 \mathrm{R}-2,60-62\end{array}$ & & & & & & & & & & & & & & & $\mathbf{R}$ \\
\hline & & & & & & & & & & & & & & & $\mathrm{R}$ \\
\hline \begin{tabular}{|ll}
$43 R-3$, & $34-36$
\end{tabular} & & & & & & & & & & & & R & $\mathrm{F}$ & & \\
\hline $43 R \cdot 3,50$ & & & & & & & & & & & - & & & & $F$ \\
\hline $43 R-3, \quad 60-62$ & & & R & & & & & & & & & & & & \\
\hline $43 \mathrm{~A}-3, \quad 92-94$ & & & & & & & & & & & & & & & \\
\hline $43 \mathrm{R}-4, \quad 34-36$ & & & & & & & & & & & & & & & \\
\hline $43 \mathrm{R}-4,50$ & & & & & & & & & & & & & R & & c. \\
\hline $43 \mathrm{R}-4,60-62$ & & & & & & & & & & & & & & & \\
\hline $43 R-4,92-94$ & & & & & & & & & & & & & R & & \\
\hline $43 \mathrm{R}-5, \quad 34-36$ & & & & & & & & & $R$ & & & & & & \\
\hline $43 \mathrm{R}-5,50$ & & & & & & & & & & & & & R & & $\mathrm{R}$ \\
\hline $43 \mathrm{R} \cdot 5, \quad 60-62$ & & & & & & & & & & & & & & & \\
\hline $43 R-5, \quad 92-94$ & & & & & & & & & & & & & & & \\
\hline$\frac{43 \mathrm{R}-\mathrm{CC}}{44 \mathrm{R}-1,50}$ & & & & & & & & & & & & & & & \\
\hline \begin{tabular}{|l|l|}
$44 \mathrm{R}-1$, & 50 \\
$4 \mathrm{R}-1,80-82$
\end{tabular} & & & & & & & & & & & & & & & \\
\hline $44 \mathrm{R}-1,80-82$ & & & & & & & & & & & & & & & \\
\hline $44 \mathrm{~A}-1, \quad 92-94$ & & & & & & & & & & & & & & & \\
\hline $44 \mathrm{R}-2, \quad 32-34$ & & & & & & & & & & & & & & & \\
\hline $44 \mathrm{R}-2,50$ & & & & & & & & & & & & & & & \\
\hline $44 \mathrm{R}-2, \quad 80 \cdot 82$ & & & & & & & & & & & & & & & \\
\hline $44 \mathrm{R} \cdot 2$, & & & & & & & & & & & & & & & \\
\hline $44 \mathrm{H}-3,32 \cdot 32$ & & & & & & & & & & & & & & & \\
\hline 年 & & & & & & & & & & & & & & & \\
\hline $44-3,800.82$ & & & & & & & & & & & & & & & \\
\hline 年 & & & & & & & & & & & & & & & \\
\hline 44A- 44. & & & & & & & & & & & & & & & \\
\hline$\frac{44 R-4}{44 R-4}$ & & & & & & & & & & & & & & & \\
\hline 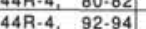 & & & & & & & & & & & & & & & \\
\hline $44 \mathrm{R} \cdot 5,32-32$ & & & & & & & & & & & & & & & \\
\hline 44R-5, 50 & & & & & & & & & & & & & & & \\
\hline $44 R-5, \quad 80-82$ & & & & & & & & & & & & & & & \\
\hline $44 R-5,92-94$ & & & & & & & & & & & & & & & \\
\hline $44 \mathrm{R}-6,32-34$ & & & & & & & & & & & & & & & \\
\hline $44 \mathrm{R}-6,50$ & & & & & & & & & & & & & & & \\
\hline 44R:6, & & & & & & & & & & & & & & & \\
\hline 44R-6, $92-94$ & & & & & & & & & & & & & & & \\
\hline $\begin{array}{l}44 R-C C \\
45 R-1,\end{array}$ & & & & & & & - & & 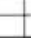 & & & - & & & $\square$ \\
\hline
\end{tabular}

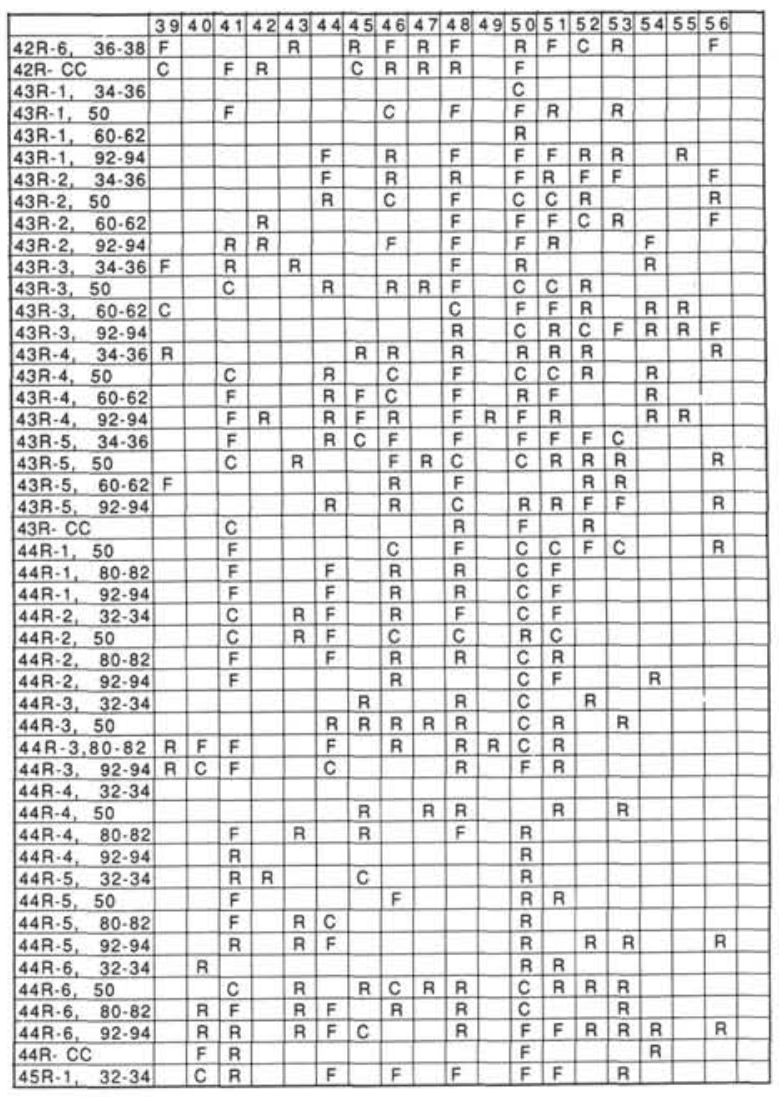



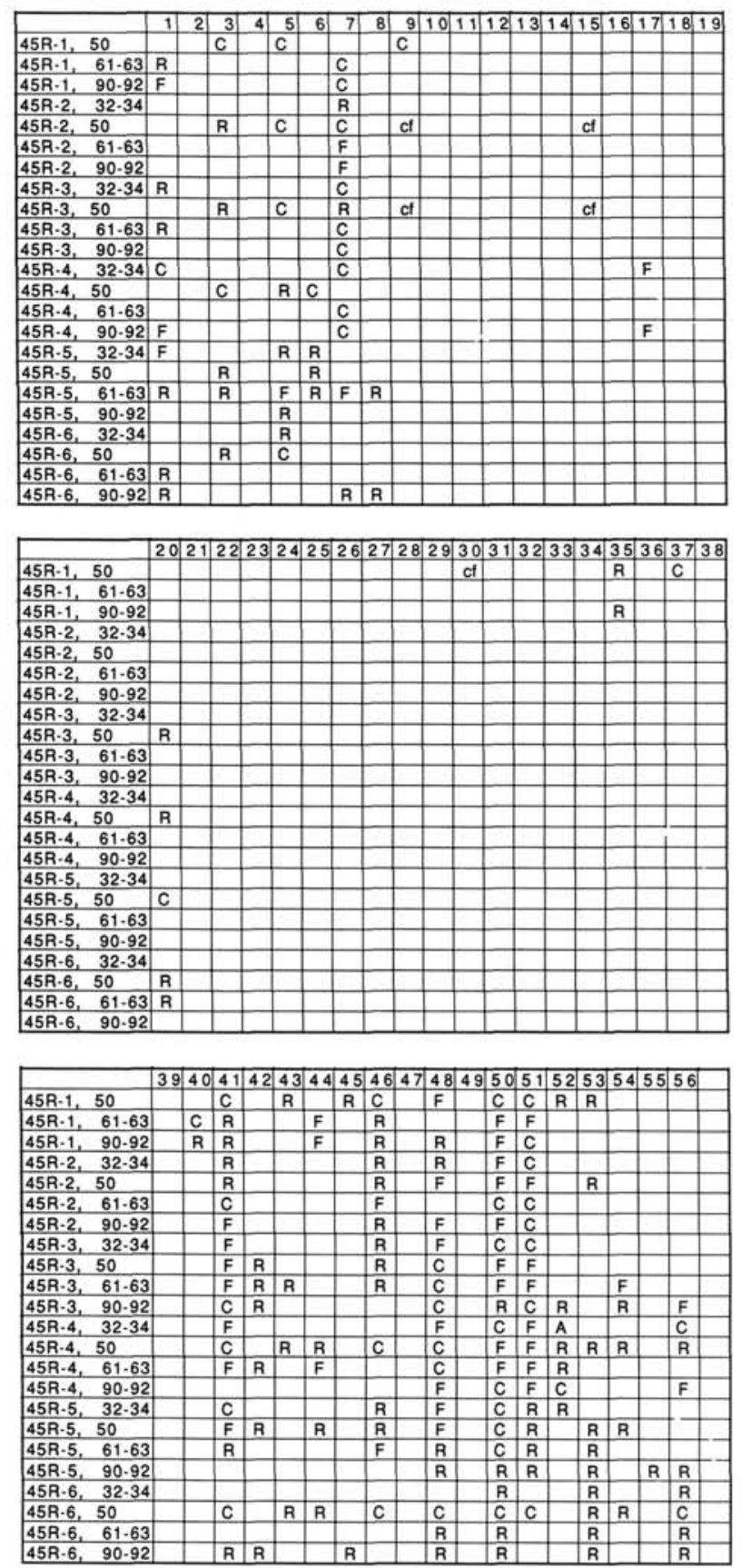

Figure 1 (continued).

3. Unit $4,55.0 \mathrm{~m}$ thick (403.9-348.9 mbsf) starts with a fining upward sequence which culminates at 391.6 mbsf (654A$44 \mathrm{R}-4,32-34 \mathrm{~cm}$ ) with sediments finer than $125 \mu \mathrm{m}$. Sediments finer than $200 \mu \mathrm{m}$ occur at 402.7 mbsf $(654 \mathrm{~A}-45 \mathrm{R}-5,32-34 \mathrm{~cm})$ but from 401 mbsf (654A-45R-4, 90-92 cm) up to $396.6 \mathrm{mbsf}$ (654A-44R-5, 80-82 cm), the sediments get coarser. Sediments finer than $200 \mu \mathrm{m}$ occur again at $393.1 \mathrm{mbsf}(654 \mathrm{~A}-44 \mathrm{R}-5,32-$ $34 \mathrm{~cm}$ ). This sequence, with sediments passing from shallow water sands to deep water nannofossil oozes, characterizes a prograding transgression. Sediments finer than $200 \mu$ m occur again at 390.1 mbsf $(654 \mathrm{~A}-44 \mathrm{R}-3,32-34 \mathrm{~cm})$. From 390.1 to 386.8 mbsf, the sediments are getting coarser; at 384 mbsf their grainsize ranges from 125 to $50 \mu \mathrm{m}$ (Fig. 2). The strong bioturbation throughout both intervals points to a sediment redistribution
Table 1. Weights of original dried samples and sieved residues.

\begin{tabular}{|c|c|c|c|c|c|}
\hline \multirow{2}{*}{$\begin{array}{l}\text { Hole } 654 \mathrm{~A} \\
\text { sample }\end{array}$} & \multirow{2}{*}{$\begin{array}{l}\text { Weight of } \\
\text { original } \\
\text { sample } \\
\text { (g) }\end{array}$} & \multicolumn{4}{|c|}{$\begin{array}{l}\text { Weight of each sieved residue } \\
\text { per } 100 \mathrm{~g} \text { of original sample ( } \mathrm{g} \text { ) }\end{array}$} \\
\hline & & & Sieve & size & \\
\hline & & & & & $50 \mu \mathrm{m}$ \\
\hline $40 \mathrm{R}-1,36-39$ & 22.90 & 0.712 & 0.148 & 0.066 & 0.279 \\
\hline $40 \mathrm{R}-1,86-89$ & 30.52 & 0.170 & 0.138 & 0.052 & 0.318 \\
\hline $40 \mathrm{R}-2,36-39$ & 24.29 & 0.000 & 0.144 & 0.161 & 0.852 \\
\hline $40 \mathrm{R}-2,86-89$ & 23.38 & 0.000 & 0.304 & 0.197 & 0.868 \\
\hline $40 \mathrm{R}-3,36-39$ & 21.61 & 0.000 & 0.444 & 0.426 & 1.185 \\
\hline $40 \mathrm{R}-3,86-89$ & 19.36 & 0.000 & 0.336 & 0.165 & 0.971 \\
\hline $40 \mathrm{R}-4,36-39$ & 21.12 & 0.000 & 0.270 & 0.360 & 1.359 \\
\hline $40 \mathrm{R}-4,86-89$ & 23.19 & 0.000 & 0.276 & 0.397 & 1.419 \\
\hline 40R-5, 36-39 & 22.13 & 0.000 & 0.601 & 0.407 & 1.753 \\
\hline $41 \mathrm{R}-1,36-39$ & 21.18 & 0.000 & 0.227 & 0.293 & 2.682 \\
\hline 4IR-1, 93-95 & 20.04 & 0.000 & 0.349 & 0.215 & 1.487 \\
\hline $41 \mathrm{R}-2,36-39$ & 18.01 & 0.000 & 0.328 & 0.439 & 1.949 \\
\hline 4IR-2, 93-95 & 17.34 & 0.000 & 0.138 & 0.063 & 0.496 \\
\hline $4 \mid \mathrm{R}-3,36-38$ & 11.06 & 0.000 & 0.353 & 0.922 & 1.374 \\
\hline $41 \mathrm{R}-3,93-95$ & 18.54 & 0.000 & 0.318 & 0.210 & 0.588 \\
\hline 4IR-4, $36-38$ & 17.83 & 0.000 & 0.780 & 0.426 & 1.644 \\
\hline 41R-4, 93-95 & 21.96 & 0.000 & 0.328 & 0.246 & 1.307 \\
\hline $42 \mathrm{R}-1,90-92$ & 13.60 & 0.000 & 0.794 & 0.507 & 2.574 \\
\hline $42 \mathrm{R}-2,36-38$ & 10.35 & 0.000 & 0.957 & 0.792 & 4.165 \\
\hline $42 \mathrm{R}-2,80-82$ & 21.22 & 0.000 & 0.448 & 0.401 & 1.423 \\
\hline $42 \mathrm{R}-2,90-92$ & 19.07 & 0.000 & 0.608 & 0.435 & 1.893 \\
\hline $42 \mathrm{R}-3,36-38$ & 17.60 & 0.000 & 0.744 & 0.443 & 2.523 \\
\hline $42 \mathrm{R}-3,82-84$ & 15.65 & 0.000 & 0.556 & 0.294 & 1.885 \\
\hline $42 \mathrm{R}-3,90-92$ & 16.27 & 0.000 & 0.676 & 0.436 & 2.243 \\
\hline $42 R-4,36-38$ & 18.34 & 0.000 & 0.562 & 0.916 & 3.271 \\
\hline $42 \mathrm{R}-4,82-84$ & 16.39 & 0.000 & 0.262 & 0.250 & 1.477 \\
\hline $42 \mathrm{R}-4,90-92$ & 18.01 & 0.000 & 0.283 & 0.183 & 1.277 \\
\hline $42 R-5,36-38$ & 17.81 & 0.000 & 0.376 & 0.410 & 1.842 \\
\hline $42 \mathrm{R}-5,90-92$ & 12.28 & 0.000 & 0.285 & 0.293 & 1.783 \\
\hline $42 \mathrm{R}-6,36-38$ & 13.38 & 0.000 & 0.239 & 0.351 & 2.130 \\
\hline $43 \mathrm{R}-1,34-36$ & 22.01 & 0.000 & 0.568 & 0.509 & 2.044 \\
\hline $43 \mathrm{R}-1,60-62$ & 17.27 & 0.052 & 0.492 & 0.307 & 2.641 \\
\hline $43 \mathrm{R}-1,92-94$ & 17.01 & 0.000 & 0.476 & 0.335 & 1.817 \\
\hline $43 \mathrm{R}-2,34-36$ & 16.21 & 0.000 & 0.432 & 0.469 & 2.116 \\
\hline $43 R-2,60-62$ & 16.62 & 0.000 & 0.644 & 0.427 & 1.649 \\
\hline $43 R-2,92-94$ & 16.13 & 0.000 & 0.577 & 1.073 & 3.180 \\
\hline $43 \mathrm{R}-3,34-36$ & 15.65 & 0.000 & 0.307 & 0.435 & 1.994 \\
\hline $43 \mathrm{R}-3,60-62$ & 19.25 & 0.000 & 0.390 & 0.395 & 2.041 \\
\hline $43 R-3,92-94$ & 16.98 & 0.000 & 0.436 & 0.406 & 1.643 \\
\hline $43 R-4,34-36$ & 16.53 & 0.000 & 0.387 & 0.653 & 2.788 \\
\hline $43 R-4,60-62$ & 11.42 & 0.000 & 0.359 & 0.525 & 3.379 \\
\hline $43 R-4,92-94$ & 17.18 & 0.000 & 0.501 & 0.215 & 3.050 \\
\hline 43R-5, $34-36$ & 19.65 & 0.000 & 0.544 & 0.529 & 2.381 \\
\hline $43 R-5,60-62$ & 14.05 & 0.000 & 0.693 & 1.338 & 2.976 \\
\hline $43 R-5,92-94$ & 19.42 & 0.000 & 0.731 & 2.507 & 18.093 \\
\hline $44 \mathrm{R}-1,32-34$ & 15.435 & 0.000 & 1.289 & 0.777 & 7.535 \\
\hline $44 \mathrm{R}-1,80-82$ & 18.07 & 0.000 & 0.515 & 1.079 & 3.857 \\
\hline $44 R-1,92-94$ & 16.96 & 0.000 & 0.501 & 1.167 & 4.245 \\
\hline $44 \mathrm{R}-1,80-82$ & 18.07 & 0.000 & 0.515 & 1.079 & 3.857 \\
\hline $44 \mathrm{R}-1,92-94$ & 16.96 & 0.000 & 0.501 & 1.167 & 4.245 \\
\hline $44 \mathrm{R}-2,32-34$ & 16.60 & 0.000 & 0.867 & 1.548 & 5.667 \\
\hline $44 \mathrm{R}-2,80-82$ & 19.05 & 0.000 & 0.572 & 0.604 & 3.805 \\
\hline $44 \mathrm{R}-2,92-94$ & 16.16 & 0.000 & 0.408 & 0.495 & 2.994 \\
\hline $44 \mathrm{R}-3,32-34$ & 18.14 & 0.000 & 0.226 & 0.391 & 1.858 \\
\hline $44 \mathrm{R}-3,80-82$ & 17.51 & 0.000 & 0.183 & 0.354 & 2.649 \\
\hline $44 \mathrm{R}-3,92-94$ & 18.61 & 0.000 & 0.167 & 0.258 & 21.321 \\
\hline $44 R-4,32-34$ & 16.46 & 0.000 & 0.000 & 0.000 & 0.936 \\
\hline $44 R-4,80-82$ & 18.43 & 0.000 & 0.000 & 0.109 & 0.825 \\
\hline $44 \mathrm{R}-4,92-94$ & 16.16 & 0.000 & 0.087 & 0.099 & 0.972 \\
\hline $44 \mathrm{R}-5,32-34$ & 17.46 & 0.000 & 0.000 & 0.115 & 0.870 \\
\hline $44 \mathrm{R}-5,80-82$ & 19.56 & 0.000 & 0.000 & 0.077 & 1.109 \\
\hline 44R-5, 92-94 & 16.70 & 0.000 & 0.060 & 0.078 & 1.623 \\
\hline $44 \mathrm{R}-6,32-34$ & 18.39 & 0.000 & 0.043 & 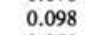 & 1.104 \\
\hline $44 \mathrm{R}-6,80-82$ & 19.97 & 0.000 & 0.316 & 0.270 & 2.724 \\
\hline $44 \mathrm{R}-6,92-94$ & 17.08 & 0.000 & 0.381 & 0.387 & 3.162 \\
\hline $45 \mathrm{R}-1,32-34$ & 16.94 & 0.000 & 0.236 & 0.337 & 1.871 \\
\hline $45 \mathrm{R}-1,61-63$ & 16.84 & 0.000 & 0.433 & 0.724 & 4.090 \\
\hline 45R-1, 90-94 & 16.07 & 0.000 & 0.224 & 0.436 & 4.057 \\
\hline $45 \mathrm{R}-2,32-34$ & 15 & & 0.346 & 0.633 & 3.775 \\
\hline $45 R-2,61-63$ & 14.82 & 0.000 & 0.490 & 0.823 & 4.648 \\
\hline 45R-2, & 19.58 & 0.000 & 0.541 & 0.837 & 4.580 \\
\hline $45 \mathrm{R}-3,32-34$ & 18.26 & 0.000 & 0.471 & 0.471 & 4.041 \\
\hline $45 \mathrm{R}-3,61-63$ & 16. & 0.000 & 0.323 & 0.603 & 4.497 \\
\hline $45 R-3,90-92$ & 16.8 & & 0.688 & 1.037 & 5.715 \\
\hline $45 \mathrm{R}-4,32-34$ & 16.11 & 0.000 & 0.925 & 1.098 & 5.026 \\
\hline $45 \mathrm{R}-4,61-63$ & 15.52 & 0.084 & 1.056 & 1.997 & 4.953 \\
\hline $45 R-4,90-92$ & 14.81 & 0.277 & 1.465 & 1.884 & 9.661 \\
\hline $45 \mathrm{R}-5,61-63$ & 19.76 & 0.167 & 1.447 & 1.305 & 4.539 \\
\hline 45R-5, 9 & & 0.303 & 1.597 & 6.423 & 5.803 \\
\hline $45 \mathrm{R}-6,32-34$ & 20 & 1.767 & 14.104 & 11859 & 8.136 \\
\hline $45 \mathrm{R}-6,61-63$ & 21.70 & 2.843 & 11.335 & 13.970 & 66 \\
\hline 45R-6, 90-92 & 21.34 & 1.579 & 8.866 & 12.667 & 18.740 \\
\hline
\end{tabular}




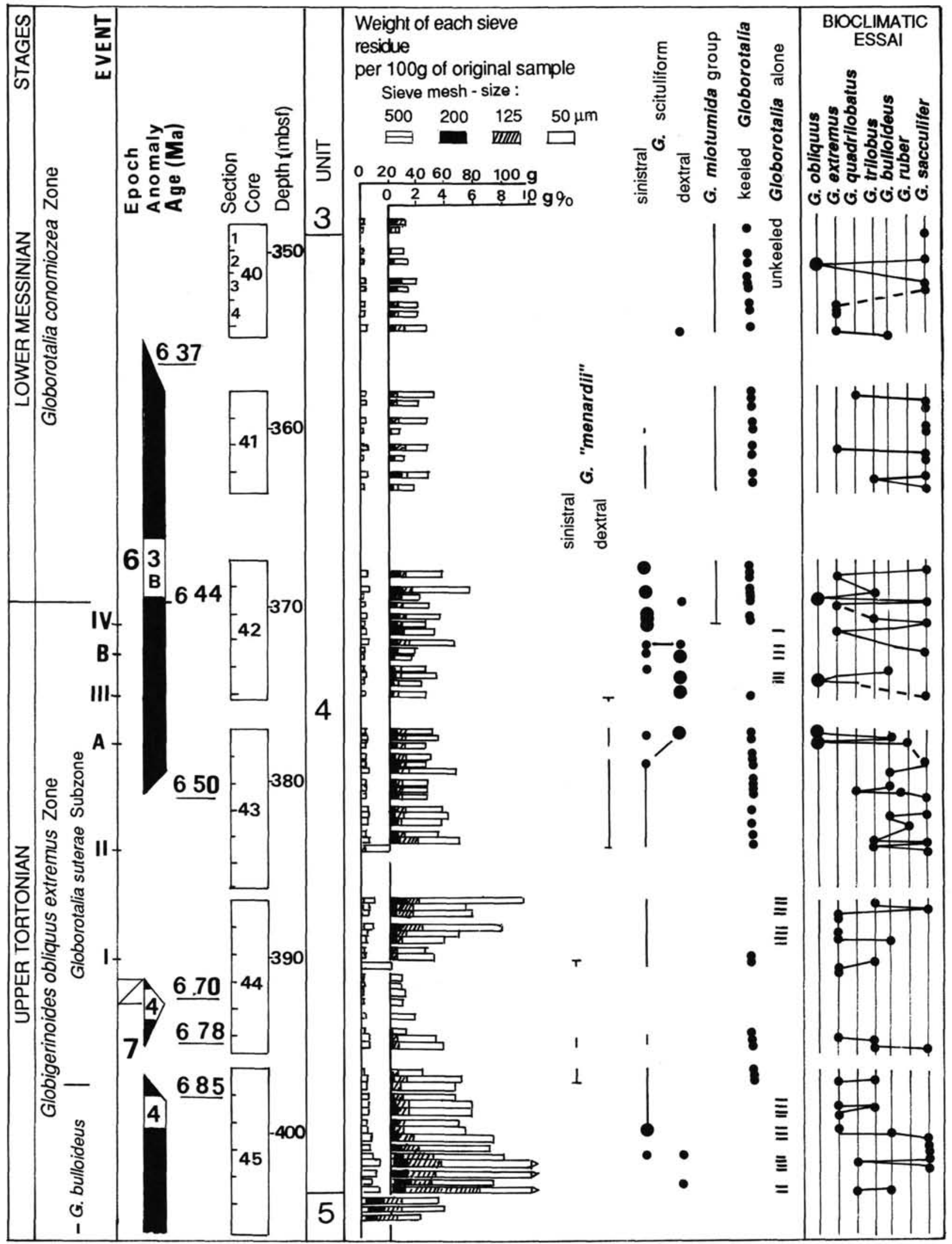

Figure 2. Stratigraphic subdivisions at Site 654 (on the left). Grain-size percentages per $100 \mathrm{~g}$ of sediment. Major planktonic events. The bioclimatic "curve" is based on the presence of species of Globigerinoides on the right). The points indicate the "warmest" species occurring in each sample, the species ranking from the coolest (on the left) to the warmest (on the right). 
through a local or a contour current rather than to a turbiditic origin. Because of their larger size (usually over $125 \mu \mathrm{m}$ ), keeled globorotaliids are absent. The rest of Unit 4 shows only a slight upward grain-size decrease. This unit yields the most diversified and better preserved foraminiferal assemblages in which the benthic assemblage is characterized by epibathyal forms.

4. Unit $5,11.8 \mathrm{~m}$ thick, (415.7-403.9 mbsf) consists of fine glauconitic sand with bioturbation. It contains large benthic foraminifers (Operculina and some Ostreid-rich levels, both suggesting a deposition in a near-shore deltaic environment. This unit passes to the nannofossil ooze of Unit 4 toward the top. The boundary between Units 5 and 4 identified in 654A$45 \mathrm{R}-5,145 \mathrm{~cm}$ (Borsetti et al., this volume), is clearly characterized by an abrupt decrease of the sand fraction (Fig. 2).

5. Unit $6,8.1 \mathrm{~m}$ thick (473.8-415.7 mbsf) consists of a conglomerate underlain and is overlain by red beds which do not contain any age-diagnostic fauna and may be related to a continental environment.

\section{PLANKTONIC FORAMINIFERAL EVENTS}

Planktonic foraminifers are abundant in Units 4 and 5 but provide a detailed stratigraphy in Unit 4 only. The entire interval belongs to the $G$. obliquus extremus and $G$. conomiozea Zones (Iaccarino and Salvatorini, 1982; Iaccarino, 1985). The late Tortonian $G$. obliquus extremus Zone ranges from the base of Unit 4 (654A-45R-5, $45 \mathrm{~cm})$ up to $369.9 \mathrm{mbsf}(654 \mathrm{~A}-42 \mathrm{R}-2,72 \mathrm{~cm})$ with $G$. suterae Subzone clearly recognizable from $396.9 \mathrm{mbsf}$ $(654 \mathrm{~A}-45 \mathrm{R}-1,50 \mathrm{~cm})$ on the base of the FO of typical specimens of $G$. suterae. The interval below 396.9 mbsf yields only forms transitional to $G$. suterae, making the assignment to the $G$. suterae Subzone not totally proved. The Messinian $G$. conomiozea Zone based on the FO of the zonal marker is detectable from 369.6 mbsf (654A-42R-2, 70-72 cm) (Shipboard Scientific Party, 1987). This zone is inferred to extend up to the laminated dolomitic mudstone, because its upper boundary defined by "the coiling shift from sinistral to dextral" of Neogloboquadrina acostaensis (Iaccarino and Salvatorini, 1982, Iaccarino, 1985) has not been detected. Rare dextral specimens of $G$. mediterranea first occur at $654 \mathrm{~A}-43 \mathrm{R}-1,50-52 \mathrm{~cm}$, slightly below the Tortonian/Messinian boundary equated to the base of the G. conomiozea Zone.

Additional events, based on distribution and coiling changes of globorotaliids have been reported on Figure 2. They are summarized together with other events described elsewhere in this volume, as follows:

\begin{tabular}{|c|c|c|c|c|}
\hline $\begin{array}{l}\text { Depth } \\
\text { (mbsf) }\end{array}$ & $\begin{array}{l}\text { Core-section, } \\
\text { interval }(\mathrm{cm})\end{array}$ & & Event & $\begin{array}{l}\text { Age } \\
\text { (Ma) }\end{array}$ \\
\hline 348.9 & $40 \mathrm{R}-1,7-5$ & $=$ & $\begin{array}{l}\text { Top of unit } 4 \text { (Borsetti et } \\
\text { al., this volume) }\end{array}$ & \\
\hline 357.34 & 40R-CC, $13-15$ & $\leftarrow$ & $\begin{array}{l}\text { Top of chron } 6 \mathrm{n} \text { (3B) } \\
\text { (Channel et al., this vol- } \\
\text { ume }\end{array}$ & 6.37 \\
\hline 358.31 & $41 \mathrm{R}-1,50-52$ & & & \\
\hline 369.63 & $42 \mathrm{R}-2,72$ & $=$ & $\begin{array}{l}\text { FO } G \text {. conomiozea (Ship- } \\
\text { board Scientific Party, } \\
\text { 1987) }\end{array}$ & 6.44 \\
\hline \multirow[t]{2}{*}{371.23} & $42 \mathrm{R}-3,82-84$ & & & \\
\hline & & $\leftarrow$ & $\begin{array}{l}\text { Entry of sinistral Globoro- } \\
\text { talia of the G. miotumida } \\
\text { lineage = Event IV }\end{array}$ & 6.45 \\
\hline 371.31 & $42 \mathrm{R}-3,90-92$ & & & \\
\hline 373.77 & $42 \mathrm{R}-5,36-38$ & & sinistral unkeeled & \\
\hline $\begin{array}{l}374.23 \\
374.31\end{array}$ & $\begin{array}{l}42 \mathrm{R}-5,82-84 \\
42 \mathrm{R}-5,90-92\end{array}$ & $\leftarrow$ & $\begin{array}{c}\text { "scituliform" Globorotalia } \\
\text { dextral = Event B }\end{array}$ & 6.46 \\
\hline 374.31 & & $\leftarrow$ & $\begin{array}{l}\text { LO dextral keeled Globoro- } \\
\text { talia }=\text { Event III }\end{array}$ & 6.47 \\
\hline
\end{tabular}

\begin{tabular}{cccc}
$\begin{array}{c}\text { Depth } \\
\text { (mbsf) }\end{array}$ & $\begin{array}{c}\text { Core-section, } \\
\text { interval (cm) }\end{array}$ & \multicolumn{1}{c}{ Event } & $\begin{array}{c}\text { Age } \\
\text { (Ma) }\end{array}$ \\
\hline 375.27 & $42 \mathrm{R}-6,36-38$ & & \\
377.71 & $43 \mathrm{R}-1,60-62$ & $\begin{array}{c}\text { dextral unkeeled } \\
\text { "scituliform" Globorotalia }\end{array}$ & 6.48 \\
378.03 & $43 \mathrm{R}-1,92-94$ & & sinistral = Event A \\
379.78 & $43 \mathrm{R}-2,117-119$ & $\leftarrow \begin{array}{l}\text { Base of chron 6n (3B) } \\
\text { (Channell et al., this } \\
\text { volume) }\end{array}$ & \\
380.95 & $43 \mathrm{R}-3,83-86$ & &
\end{tabular}

$\begin{array}{ll}380.95 & 43 R-3,83-86 \\ 383.71 & 43 R-5,60-62\end{array}$

$\leftarrow$ Entry of dextral keeled Globorotalia $=$ Event $\mathrm{II}$

6.56

$384.03 \quad 43 R-5,92-94$

43R-5, 92

$=$ FAD Amaurolithus tricorniculatus fide C. Müller, this volume

$389.23 \quad 44 \mathrm{R}-2,92-94$

$\leftarrow \quad$ LO of sinistral keeled Globorotalia (in situ or reworked?) = Event $\mathrm{I}$

$390.13 \quad 44 \mathrm{R}-3,32-34$

$391.63 \quad 44 \mathrm{R}-4,32-34$

391.07 44R-3, 126-128

$=$ Sediment grain size smaller than $125 \mu \mathrm{m}$

$\leftarrow \quad$ Top of chron 7n1 (4) (Channell et al., this volume)

$392.71 \quad 44 \mathrm{R}-4,140-142$

393.73 44R-5, 92-94
$\leftarrow$ Disappearance or last occur- rence (LO)? of sinistral keeled Globorotalia = Event I?

$394.63 \quad 44 \mathrm{R}-6,32-34$

392.71 44R-4, 140-142
$\leftarrow$ Base of chron $7 \mathrm{n} 1$ (4) (Channell et al., this volume)

395.39 44R-6, 108-110

396.81 45R-1, 40-42

$\leftarrow \quad$ Top of chron 7n2 (4) (Channel et al., this volume)

6.85

398.41 45R-1, 50-52

$399.90 \quad 45 \mathrm{R}-3,50$

403.9 45R-5, 145

$=$ FO of Globorotalia suterae

$=$ Base of unit 4 (Borsetti et al., this volume)

Events which are related to keeled globorotaliids are indicated with roman numbers, events related to unkeeled globorotaliids are indicated with capital letters. All events have been correlated to the geomagnetic time-scale (Berggren et al., 1985) and their interpolated ages have been calculated using those proposed by Chanell et al. (this volume).

Event $\mathrm{I}$. This event is defined by the exit of sinistral keeled Globorotalia including the $G$. plesiotumida-G. merotumida group, G. menardii form 4 of Tjalsma (1971) and Zachariasse (1975), and $G$. menardii group 1 of Sierro et al. (1987). This event is not clearly detectable. In fact sinistral keeled globorotaliids occur discontinuously from 393.7 mbsf $(654 \mathrm{~A}-45 \mathrm{R}-5,90-92)$ up to 390.13 mbsf (654A-44R-3, $80-82 \mathrm{~cm})$. The absence of sinistral keeled globorotaliids in Core 654A-44R (Sections 4 and 5) is probably due to resedimentation processes which gave origin to sediments too fine $(<125 \mu \mathrm{m})$ to yield those foraminifers. Therefore, it is not excluded that reappearance of this group of globorotaliids between $654 \mathrm{~A}-34 \mathrm{R}-3,92-94 \mathrm{~cm}$, and $654 \mathrm{~A}-44 \mathrm{R}-3$, $80-82 \mathrm{~cm}$, could be due to reworking.

Event II. This event is characterized by the arrival of dextral keeled Globorotalia including G. cultrata group, G. menardii form 5 of Tjalsma (1971), Zachariasse (1975) and G. menardii 
group 2 of Sierro et al. (1987). This event occurs at $389.7 \mathrm{mbsf}$ (654A-43R-5, 60-62 cm). This group of globorotaliids, which have flatter profile, slightly more evolute spire and more open umbilicus in comparison with the previous ones, range up to $374.31 \mathrm{mbsf}(654 \mathrm{~A}-42 \mathrm{R}-5,90-92 \mathrm{~cm})$ where they reduce drastically in number (Event III).

Event $\mathrm{A}$. This event is defined by the change of sinistral to dominant dextral coiling direction of the unkeeled "scituliform" globorotaliids (including G. cibaoensis, G. juanai, G. premargaritae, $G$. ventriosa, $G$. suterae, $G$. exserta). This event occurs at 377.7 mbsf $(654 \mathrm{~A}-43 \mathrm{R}-1,60-62 \mathrm{~cm})$ within the range of the dextral keeled globorotaliids.

Event B. This event is characterized by the change of dextral to dominantly sinistral coiled unkeeled "scituliform" globorotaliids occurring at 373.7 mbsf $(654 \mathrm{~A}-42 \mathrm{R}-3,36-38 \mathrm{~cm})$. This group remains consistently sinistral up to the top of the sequence. Rare specimens of dextral forms occur at $361.18 \mathrm{mbsf}$ (654A-41R-3, 36-38 cm) and at 354.7 mbsf (654A-40R-5, 50 $\mathrm{cm})$.

Event IV. This event consists of a sudden increase in number of left coiled planoconvex keeled globorotaliids of the G. miotumida group of Sierro (1985) or G. dalii Tjalsma (1971) which replace dextral keeled Globorotalia. This event, occurring at 371.2 mbsf (654A-42R-3, 82-84 cm) predates the FO of $G$. conomio$z e a$ at $654 \mathrm{~A}-42 \mathrm{R}-2,70-72 \mathrm{~cm}$. This sudden increase could either reflect a local Mediterranean bloom of keeled globorotaliids or may result from a sudden inflow of Atlantic waters at intermediate depths.

\section{COMPARISON WITH OTHER AREAS}

The events recognized at Site 654 can be correlated with similar events previously identified within the same time interval, in northern Morocco sections (Feinberg and Lorenz, 1970; Bossio et al., 1976; Wernli, 1977), in Spain (Tjalsma, 1971; Sierro, 1985; and Sierro, in press), in the Atlantic Ocean (Sierro, in press), in the eastern Mediterranean (Crete) (Zachariasse, 1975), and Italy (D'Onofrio et al., 1975; Colalongo et al., 1979).

\section{Mediterranean-Atlantic Pathways and Adjacent Atlantic Ocean}

There are strong correlations in both facies and biostratigraphy between the western margin of the Tyrrhenian Basin, the northwestern margin of the Guadalquivir Basin in southern Spain (Fig. 3), and the South Riffean Basin in northern Morocco. In all three areas, the marine sedimentation begins with shallow water sediments of late Tortonian age associated with or passing to glauconitic sands. During the latest Tortonian (younger than $7.0 \mathrm{Ma}$ ), this sequence rapidly grades into deep water hemipelagic nannofossil oozes. This stratigraphic succession has been documented also by Bossio et al. (1976), Wernli (1978), and Cita and Ryan (1978). It also corresponds to the "sahelian cycle" of Ricci Lucchi et al. (1982).

Close to the Tortonian/Messinian boundary, the foraminiferal events seen in the Tyrrhenian Sea are correlatable with those from other areas as follows (from bottom to top) (Fig. 2):

Event I correlates well with the disappearance of G.menardii form 4 Tjalsma, 1971 in the Guadalquivir Basin (Event 1 of Sierro, 1985), with the exit of the sinistral keeled Globorotalia at DSDP Site 410 from central North Atlantic, and with a drastic reduction of the same forms in northern Morocco.

Event II correlates well with the entry of dextral G. menardii form 5 Tjalsma, 1971 in Guadalquivir Basin (Event 2 of Sierro, 1985), with the entry of dextral forms of $G$. "menardii" group of Sierro (1985) in northern Morocco, and at DSDP Sites 410 and 397 (Sierro, in press).
Event A has been reported in the Atlantic (DSDP Sites 410, 397, and 334) and in Morocco (Oued Akrech) (Sierro, in press). It occurs during anomaly $3 \mathrm{~B}$, as in the Tyrrhenian Sea.

In the Tyrrhenian Sea, Events III and IV are separated by an interval without dextral keeled globorotaliids. In the Guadalquivir Basin, the south Riff Basin and DSDP Site 410 in the Central North Atlantic, Events III and IV are represented by only one event (Event 3 of Sierro, 1985), and the keeled dextral globorotaliids are followed directly by the " $G$. miotumida group" (sensu Sierro, 1985). This difference may be explained either by actual differences between the three areas, or by a higher biostratigraphic resolution in the Tyrrhenian Sea, where the deposition rate, for this interval, is estimated at about $165 \mathrm{~m} / \mathrm{Ma}$ (Channell et al., this volume).

A similar succession of events has also been found in the Alboran Sea, at DSDP Site 121 (Montenat and Bizon, 1976).

The coiling change from sinistral to dextral Neogloboquadrina acostaensis is a worldwide event. It has been recorded in many areas of the Mediterranean Sea below the Messinian evaporites (Zachariasse, 1975; Colalongo et al.,1979; and Spaak, 1983), in the Guadalquivir Basin (Sierro, 1985), in the South Riff Basin (Bossio et al., 1976; El Bied, pers. comm.) and in several DSDP sites from the north Atlantic (Salvatorini and Cita, 1979; Sierro et al., in press), but it was not recorded at Site 654A. Therefore, either a hiatus occurs between Units 4 and 3, or the evolution of the Tyrrhenian Sea toward restricted marine conditions started before the time of this event. Because hiatuses have already been documented in other parts of the Mediterranean area for the same time interval, we would favor this first hypothesis (d'Onofrio et al., 1975; Colalongo, 1979).

\section{Eastern Mediterranean: Crete}

Events I to IV can be correlated with similar events in Crete (Zachariasse, 1975, 1979a). Because the paleomagnetic record of Site 654A is ambiguous (Channell et al., this volume), the synchroneity of the events is uncertain. According to Langereis et al. (1984) the FAD of $G$. conomiozea occurs in the middle part of Chron 5 below anomaly $3 \mathrm{~A} 1$, at $5.6 \mathrm{Ma}$. Berggren et al. (1985) and Hsü (1986), reinterpreting Langereis et al.'s magnetostratigraphy, estimate an age of $6.1 \mathrm{Ma}$, in agreement with the age proposed by Loutit and Kennett (1979) for the evolutionary appearance of $G$. conomiozea in New Zealand. Following the interpretation of Channell et al. (this volume), the estimated interpolated age of Event IV is $6.45 \mathrm{Ma}$, and that of G. conomio$z e a$ FO should be $6.44 \mathrm{Ma}$. The age of the first occurrence of $G$. conomiozea is therefore still a matter of debate.

\section{Italy: Sicily and Piemonte}

The major biostratigraphical events, such as the FO of Globorotalia suterae and the FO of G. conomiozea, are well correlatable with those identified in the Italian land sections (D'Onofrio et al., 1975; Colalongo et al., 1979), whereas the other aforementioned events were not detected at that time, and correlation with Site 654 is not immediately readable. However, according to Colalongo et al. (1979), G. miotumida becomes common in the upper part of the G. suterae Subzone, and this datum can be correlated with the Event IV (entry of sinistral coiled globorotaliids of the $G$. miotumida group) which predates the FO of $G$. conomiozea. The remarkable decrease of $G$. cultrata group, noticed by d'Onofrio et al. (1975), can be related to the Event III (last occurrence of dextral keeled globorotaliids).

Conversely, some discrepancies occur between Site 654 and Italian land sections in the stratigraphic position of the first occurrence of some species (Globorotalia saheliana, G. exserta, and $G$. nicolae). 


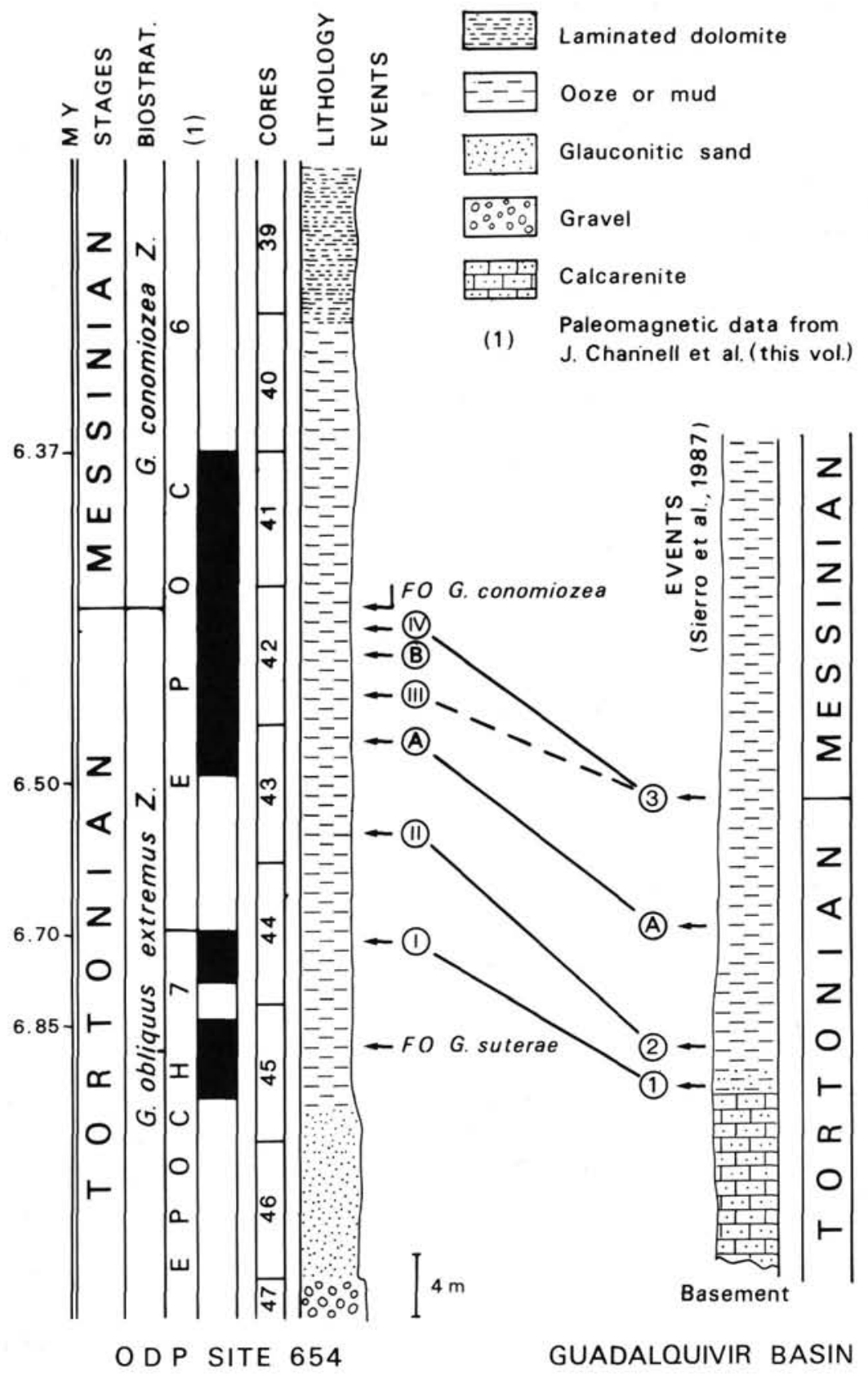

Figure 3. Correlation between planktonic foraminifera events at Site 654 and in the Guadalquivir Basin:

ODP Hole 654, Leg 107

I = Exit of sinistral keeled globorotaliids

II = Entry of dextral keeled globorotaliids

A $=$ Sinistral to dextral change in the unkeeled globorotaliids

III = Exit of dextral keeled globorotaliids

$\mathrm{B}=$ Dextral to sinistral change in the unkeeled globorotaliids

IV = Entry of the "Globorotalia miotumida" group (sensu Sierro).

Guadalquivir Basin

1 = Exit of sinistral keeled globorotaliids

$2=$ Entry of dextral keeled globorotaliids

A $=$ Sinistral to dextral change in the unkeeled globorotaliids

3 = Entry of the "Globorotalia conoidea-miotumida" group (sensu Sierro). 


\section{PALEOENVIRONMENTAL APPROACH}

\section{Foraminifers}

On the whole, the foraminiferal assemblage of the late Miocene sequence of Site 654 reflects warm water masses. Subtropical species are in fact common.

A tentative interpretation of surface water paleoenvironmental evolution is proposed, using the occurrence of near surface dwelling species of Globigerinoides, which record environmental variations of surficial waters (mainly temperature and salinity) (Fig. 2). On the basis of semiquantitative analysis, carried out throughout the entire sequence, from seafloor downward, some species and morphotypes, belonging to the genus Globigerinoides suggest a ranking from "coolest" to "warmest" as follows: Globigerinoides obliquus, G. extremus, G. quadrilobatus, G. trilobus, G. bulloideus, G. ruber, and G. sacculifer. In order to understand the bioclimatic trial, summarized in Figure 2 , dotted points refer to the occurrence of the "warmest" species in each sample.

Figure 2 also shows that the genus Globigerinoides never disappears through the investigated interval. G. obliquus is always present. The presence of this species alone in five intervals of the sequence points to "cooler" conditions at: 654A-40R-2, 86$89 \mathrm{~cm}, 42 \mathrm{R}-2,50 \mathrm{~cm}, 42 \mathrm{R}-5,82-84 \mathrm{~cm}, 43 \mathrm{R}-1,34-36 \mathrm{~cm}$, and $43 \mathrm{R}-1,60-62 \mathrm{~cm}$. Other cool episodes are suggested by the cooccurrence of $G$. obliquus and $G$. obliquus extremus at: $654 \mathrm{~A}$ $40 \mathrm{R}-4,36 \mathrm{~cm}, 654 \mathrm{~A}-40-5,39 \mathrm{~cm}, 654 \mathrm{~A}-41 \mathrm{R}-3,36-38 \mathrm{~cm}, 654 \mathrm{~A}-$ 42R-1, 82-92 cm, 654A-42R-2, 90-92 cm, 654A-42R-3, 90-92 $\mathrm{cm}, 654 \mathrm{~A}-44 \mathrm{R}-1,80 \mathrm{~cm}, 654 \mathrm{~A}-44 \mathrm{R}-2,82 \mathrm{~cm}, 654 \mathrm{~A}-44 \mathrm{R}-3,82-94$ $\mathrm{cm}, 654 \mathrm{~A}-44 \mathrm{R}-6,32-34 \mathrm{~cm}, 654 \mathrm{~A}-45 \mathrm{R}-1,61 \mathrm{~cm}, 654 \mathrm{~A}-45 \mathrm{R}-2,34$ $\mathrm{cm}, 654 \mathrm{~A}-45 \mathrm{R}-2,61,654 \mathrm{~A}-45 \mathrm{R}-3,34 \mathrm{~cm}$, and 654A-45R-5, 90 $92 \mathrm{~cm}$.

By comparing the Globigerinoides assemblages with the events discussed above, it appears that the lower "coolest" peak correlates with the sinistral to dextral change of "scituliform" globorotaliids (Event $\mathrm{A}$ ).

\section{The Stable Isotope Records}

Analytical results on stable isotopes are reported in Table 2 and are plotted against absolute ages in Figures 4 and 5. Interpolated and extrapolated ages were calculated using biostratigraphic and magnetostratigraphic event dates reported above. Since the records correspond to a time interval of about $0.7 \mathrm{Ma}$, the resolution of the data may be estimated to be around 0.02 Ma.

One may observe three notable events of ${ }^{18} \mathrm{O}$ enrichment in the sequence, between 402 and 397 mbsf, between 376 and 382 mbsf, and between 350 and 355 mbsf (with peaks values at $654 \mathrm{~A}-40 \mathrm{R}-4,36 \mathrm{~cm}$, and $654 \mathrm{~A}-40 \mathrm{R}-2,86 \mathrm{~cm}$ ). The interpolated ages of these episodes of ${ }^{18} \mathrm{O}$ enrichment are of about $7.05 \mathrm{Ma}$, $6.75 \mathrm{Ma}$, and $6.35 \mathrm{Ma}$, respectively. The highest $\delta^{18} \mathrm{O}$ values, around $+1.1 \%$, are reached at the top of the sequence, near $353 \mathrm{mbsf}(\sim 6.35 \mathrm{Ma})$. Low $\delta^{18} \mathrm{O}$ values, of about $-1.5 \%$, occur between 397 and 400 mbsf, 382 and 385 mbsf, 360 and 370 mbsf, and near $347 \mathrm{mbsf}$ at about $6.95 \mathrm{Ma}, 6.55 \mathrm{Ma}, 6.45 \mathrm{Ma}$, and $6.3 \mathrm{Ma}$, respectively. The overall range of $\delta^{18} \mathrm{O}$ variations is thus around $2.5 \%$.

The $\delta^{13} \mathrm{C}$ record gives also a high amplitude signal. The overall $\delta^{13} \mathrm{C}$ values range between $+2.5 \%$ and $+0.5 \%$. The lowest $\delta^{13} \mathrm{C}$ values are recorded near $395 \mathrm{mbsf}(\sim 6.8 \mathrm{Ma})$ and at 351 mbsf $(\sim 7.0 \mathrm{Ma})$. The highest $\delta^{13} \mathrm{C}$ values are recorded at the base of the sequence, near 402 mbsf $(\sim 7.0 \mathrm{Ma})$. The most prominent feature in the carbon isotope record is a peak of high $\delta$ values at the base of the record $(\sim 7.0 \mathrm{Ma})$ which is followed by a rapid decrease between 7.0 and $6.9 \mathrm{Ma}$. Other episodes of decreasing $\delta^{13} \mathrm{C}$ values occur in the sequence, around $387 \mathrm{mbsf}$,
Table 2. Oxygen and carbon isotopic composition of Globigerinoides obliquus and $G$. quadrilobatus (corrected for equilibrium values). All data are expressed against the PDB1 Standard.

\begin{tabular}{|c|c|c|c|c|}
\hline $\begin{array}{l}\text { Hole } 654 \mathrm{~A} \\
\text { samples }\end{array}$ & $\begin{array}{l}\text { Depth } \\
\text { (mbsf) }\end{array}$ & $\begin{array}{c}\text { Age } \\
(\times \text { k.y. })\end{array}$ & $\begin{array}{c}\delta^{18} \mathrm{O} \text { obliquus } \\
(\% 0)\end{array}$ & $\begin{array}{c}\delta^{13} \mathrm{C} \text { obliquus } \\
(\% 0)\end{array}$ \\
\hline $40-1-80$ & 349 & 8320 & -1.17 & 1.56 \\
\hline $40-2-86$ & 350.56 & 6330 & 0.85 & 0.95 \\
\hline $40-3-36$ & 351.06 & 6340 & -0.54 & 0.40 \\
\hline $40-3-86$ & 352.06 & 6350 & -0.22 & 0.77 \\
\hline $40-4-36$ & 353.06 & 6370 & 0.83 & 0.57 \\
\hline $40-4-86$ & 353.56 & 6360 & 1.09 & 0.99 \\
\hline $40-5-38$ & 354.56 & 6380 & 0.44 & 0.88 \\
\hline $41-1-80$ & 358.6 & 6400 & -1.17 & 1.56 \\
\hline $41-3-36$ & 361.16 & 8440 & -1.17 & 0.95 \\
\hline $42-2-80$ & 369.7 & 6448 & -1.29 & 0.91 \\
\hline $42-3-36$ & 370.76 & 6449 & & 1.20 \\
\hline $42-4-82$ & 372.72 & 6455 & -0.73 & 1.18 \\
\hline $42-4-90$ & 372.82 & 8458 & -1.03 & 1.25 \\
\hline $42-6-36$ & 375.26 & 6470 & -0.31 & 0.6 \\
\hline $42-5-80$ & 378.5 & 8475 & -0.80 & 1.56 \\
\hline $43-2-34$ & 378.94 & 8489 & -0.21 & 1.05 \\
\hline $43-2-62$ & 379.22 & 8492 & & \\
\hline $43-2-92$ & 379.52 & 6495 & & \\
\hline $43-4-60$ & 382.22 & 6533 & & \\
\hline $43-4-92$ & 382.52 & 6537 & -0.37 & 1.17 \\
\hline $43-5-34$ & 383.54 & 6552 & -1.55 & 1.87 \\
\hline $44-1-92$ & 387.72 & 6848 & -0.93 & 0.81 \\
\hline $44-2-32$ & 388.62 & 6687 & & \\
\hline $44-2-80$ & 389.1 & 6879 & -0.99 & 0.93 \\
\hline $44-2-92$ & 389.22 & 6681 & -0.41 & 1.51 \\
\hline $44-3-80$ & 390.6 & 6712 & -0.38 & 1.25 \\
\hline $44-4-92$ & 392.22 & 6744 & & \\
\hline $44-6-92$ & 395.22 & 6848 & -0.45 & 0.48 \\
\hline $44-6-20$ & 396.12 & 6899 & -0.18 & 0.82 \\
\hline $45-1-31$ & 396.71 & 6933 & -1.2 & 0.68 \\
\hline $45-2-32$ & 398.53 & 6978 & -0.23 & 2.25 \\
\hline $45-2-61$ & 398.84 & 6981 & -0.43 & 1.81 \\
\hline $45-2-90$ & 399.13 & 6986 & -1.64 & 1.11 \\
\hline $45-3-61$ & 400.32 & 7002 & -0.96 & 2 \\
\hline $45-4-32$ & 401.82 & 7020 & -0.73 & 1.94 \\
\hline $45-4-90$ & 402.42 & 7037 & 0.05 & 2.65 \\
\hline
\end{tabular}

$377 \mathrm{mbsf}$, between 370 and $360 \mathrm{mbsf}$, and near $352 \mathrm{mbsf}$, i.e., at about $6.85 \mathrm{Ma}, 6.55 \mathrm{Ma}, 6.45 \mathrm{Ma}$, and $6.35 \mathrm{Ma}$, respectively.

\section{INTERPRETATION}

\section{The $\delta^{18} \mathrm{O}$ Record}

No clear trend can be read on the 7.1 to $\sim 6.3 \mathrm{Ma}$ oxygen isotope record of the Tyrrhenian Sea. $\delta^{18} \mathrm{O}$ values higher than $1 \% 0$ are not recorded prior to $1.5 \mathrm{Ma}$ in the early Pleistocene of Hole 653A (Vergnaud Grazzini et al., this volume), while the lowest $\delta^{18} \mathrm{O}$ values of Site 654 are similar to those recorded in the early Pliocene of Hole 653A. Various studies have interpreted oxygen isotope increases in the open ocean as indicating major expansion of the Antarctic ice cap (Shackleton and Kennett, 1975; Cita and Ryan, 1979; McKenzie et al., 1984; McKenzie and Oberhänsli, 1985; among others). These interpretations, however were based on sites that were sampled at too large intervals to resolve with precision the true nature of late Miocene climatic variability. More recent studies on North Atlantic DSDP cores, well tied to the magnetic stratigraphy, however, suggest that there is little oxygen-isotope evidence for a prolonged glaciation during the last $2 \mathrm{Ma}$ of the Miocene time. The first true glacial maxima should have occurred at 5.5 and $5.0 \mathrm{Ma}$ (Keigwin et al., 1987). This latter interpretation slightly contradicts that of McKenzie and Oberhänsli (1985) based on the oxygen isotope record of Site 519 in the South Atlantic. These authors attributed the fluctuations in the oxygen isotope values, between 6.7 and $5.1 \mathrm{Ma}$, to repeated phases of glacial enhance- 


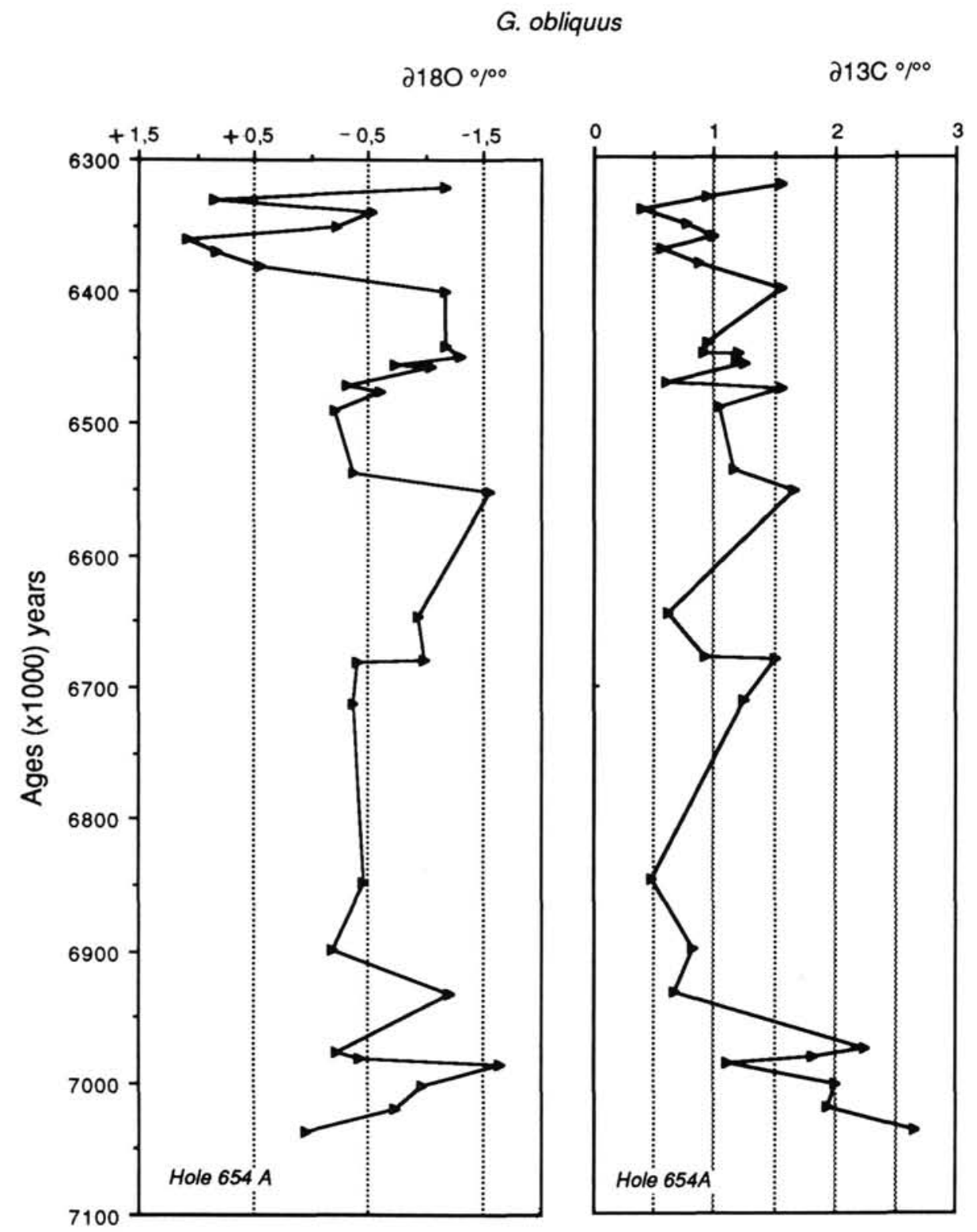

Figure 4. Oxygen and carbon isotope data reported against estimated ages calculated by interpolation of paleomagnetic and biostratigraphic dates. The composite curves have been built using $G$. quadrilobatus $\delta^{13} \mathrm{C}$ and $\delta^{18} \mathrm{O}$ values corrected by $-0.23 \%$ and $-0.20 \%$, respectively.

ment during the latest Miocene and to the instability of the West Antarctic ice sheet, which could have been established by around 7 Ma (Rutford et al., 1972).

The lack af any benthic record at Site 654 however makes it difficult to interpret the changes in the $\delta^{18} \mathrm{O}$ values of planktonic forms alone. Part of the signal may result from a temperature effect. Unless some glacio-eustatic sea level change could be documented for this time interval in the Tyrrhenian basin, we should attribute part of the measured ${ }^{18} \mathrm{O}$ variations to local salinity effects. Tectonic readjustments, as well as changes in the geometry of the basin, might have induced changes in the water masses circulation pattern, and in the local water budget of the basin. This, in turn, might have induced high amplitude $\delta^{18} \mathrm{O}$ fluctuations (about 1.5\% higher than those recorded in the open Atlantic Hole 552A at the same time) (Keigwin et al., 1987). It remains difficult however to adduce evidence whether the high ${ }^{18} \mathrm{O}$ fluctuations recorded in the late Miocene Mediter- ranean sediments, correspond to an amplification of the global climatic signal, or are an independent response to local tectonics and paleoceanography. In fact, the low resolution of the data available for other Mediterranean sections (DSDP Site 372, Vergnaud Grazzini, 1975; Carmona, Spain, Loutit and Keigwin, 1982; Sorbas, Spain; Müller, in press; among others) does not allow correlations to be made with confidence. The high $\delta^{18} \mathrm{O}$ values and low $\delta^{13} \mathrm{C}$ values which are recorded slightly below the deposition of evaporitic facies at the top of the sequence strongly suggest an important local overprint.

\section{The $\delta^{13} \mathbf{C}$ Record}

The $\delta^{13} \mathrm{C}$ values decrease by about $2 \%$ between about 7.0 and 6.9 Ma at the base of the sequence. A decrease in $\delta^{13} \mathrm{C}$ values within Chronozone 6 has been widely reported in studies of the late Miocene (Keigwin, 1979; Vincent et al., 1980; Shackleton et al., 1984; Keigwin et al., 1987; among others) and has 


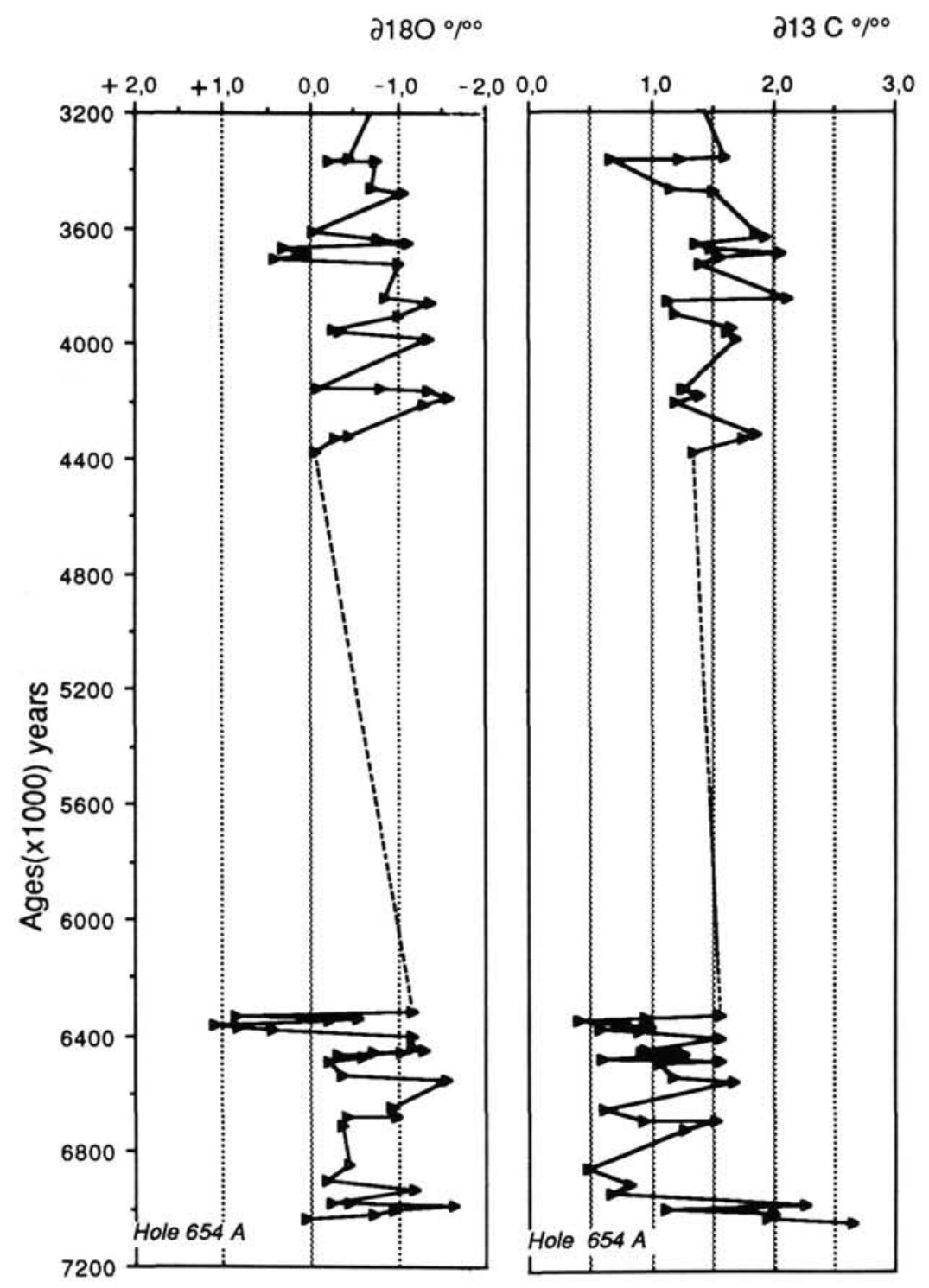

Figure 5. The stable isotope records of $G$. obliquus from the late Miocene section to the early Pliocene of Hole 654A.

been dated at 6.2 Ma using paleomagnetic stratigraphy in a few sites (Loutit and Kennett, 1979; Keigwin and Shackleton, 1980; Keigwin et al., 1987). This ${ }^{13} \mathrm{C}$ decrease has proved a useful stratigraphic marker in the Indo-Pacific, South Atlantic, and North Atlantic Oceans. In addition, high resolution studies in the North Atlantic (Keigwin et al., 1987) suggest that changes in the $\delta^{13} \mathrm{C}$ values of surface and deep dwelling foraminifers reflect variability in the $\delta^{13} \mathrm{C}$ of the total $\mathrm{CO}_{2}$ in seawater rather than changes in the deep-sea circulation. In particular, the authors did not find any carbon isotope evidence for a deep-sea circulation change in the North Atlantic resulting from the Messinian salinity crisis. Moreover, in most of the North Atlantic sites, a peak of maximal $\delta^{13} \mathrm{C}$ values is recorded both by planktonic and benthic foraminiferal species near 7.0 Ma (Holes 610E, 611C, 552A, Keigwin et al.,1987) and predates the decreasing trend of the carbon shift. We suggest that the ${ }^{13} \mathrm{C}$ maximum reported at Site 654 near 7.0 Ma reflects the same global signal registered in the North Atlantic Sites. No significant trend can be read, how- ever, in the following upper part of the ${ }^{13} \mathrm{C}$ record. The fluctuations which occur around a $1 \%$ average $\delta$ value are similar in amplitude to those recorded before $3.2 \mathrm{Ma}$ at ODP Hole $653 \mathrm{~A}$ in the Tyrrhenian basin (Vergnaud Grazzini et al., this volume).

\section{CONCLUSIONS}

The late Miocene sediments of ODP Hole 654A (from 403 to $348 \mathrm{mbsf}$ ), including the lithologic Unit 4 and part of Unit 3 have been sampled for biostratigraphic and stable isotope studies. In addition, preliminary grain-size analysis has been performed on part of the samples. Our results indicate that the stratigraphic section spans an interval of nearly 0.7 m.y., between approximately 7.0 and $6.3 \mathrm{Ma}$. The Mediterranean late Miocene biozonation has been recognized. The G. suterae Subzone and the $G$. conomiozea Zone are clearly identified. Correlation of paleomagnetic data to the geomagnetic time-scale suggests that the Tortonian/Messinian boundary should be aged as near 6.44-6.45 Ma. Other paleontological events such as the LO 
of sinistral keeled globorotaliids (Event I), the FO and LO of dextral keeled globorotaliids (Events II and III), the sinistral to dextral (Event A) and dextral to sinistral (Event B) coiling changes in the "scituliform" globorotaliids and the increase in abundance of left planoconvex keeled $G$. miotumida group (Event IV) have been identified. These events are well correlatable with similar events reported from Southern Spain, Northern Morocco, and North Atlantic Ocean. In particular, Event IV is very close to the FO of $G$. conomiozea, and we therefore suggest that it might be used to recognize the Tortonian/Messinian boundary in areas where $G$. conomiozea is absent or very rare. The paleoenvironmental interpretation suggests that increases in the diversity of the Globigerinoides group correlate with decreases in the $\delta^{18} \mathrm{O}$ values of $G$. obliquus. By contrast, decreases in the diversity of the Globigerinoides group (with $G$. obliquus being the dominant species) correlate with increases in the $\delta^{18} \mathrm{O}$ values. Although no clear trends can be recognized on the oxygen and carbon isotope records of $G$. obliquus, the parallelism between the occurrence of low salinity species ( $G$. sacculifer) and peaks of low $\delta^{18} \mathrm{O}$ values as well as that of normal salinity species ( $G$. obliquus and peaks of high $\delta^{18} \mathrm{O}$ values, suggests strong local changes of environmental conditions. $\delta^{18} \mathrm{O}$ values as high as those recorded in the early glacial cycles of the Pleistocene (ODP Hole 653A) are recorded three times in the sequence. Because similar increases have not yet been reported for the open ocean we suggest that they may be related to local changes of the Tyrrhenian water budget and are independent from global climatic changes. By contrast, a peak of high $\delta^{13} \mathrm{C}$ values recorded at $7.0 \mathrm{Ma}$ may be correlated with a similar event reported in North Atlantic sites. The strong ${ }^{13} \mathrm{C}$ decrease recorded between 7.0 and $6.95 \mathrm{Ma}$ predates the global Miocene carbon shift (at 6.2 Ma). On the whole, these data suggest that, after 7.0 Ma, important local overprints, tied to the evolution of the basin toward evaporitic conditions, obliterated and/or complicated the global ${ }^{13} \mathrm{C}$ and ${ }^{18} \mathrm{O}$ signals.

\section{TAXONOMIC NOTES}

Some differences exist in the taxonomic concept of Globorotalia conomiozea. According to Scott (1980) and Zachariasse (1979b), G. conomiozea s.s. does not exist in the Mediterranean. According to Zachariasse (1975, 1979b), Mediterranean G. conomiozea refers to left coiled planoconvex keeled globorotaliids having on average 4.5 crescent shape chambers in the last whorl. However conical forms with only 4 chambers in the last whorl as G. conomiozea are documented by D'Onofrio et al. (1975) and Colalongo et al. (1979), and Bossio et al. (1976). Different opinions exist also about the taxonomy of $G$. conoidea and $G$. conomiozea. According to Sierro et al. (1987), both species belong to the $G$. miotumida group and the different names depend on "the region where they are found." According to one of the authors (S. I.), G conoidea does not evolve from $G$. miotumida and thereby it cannot be considered as belonging to the same group. Most likely it derives from $G$. miozea. That $G$. conoidea evolves from different ancestors is supported by its occurrence in levels older than Event 2 (Sierro, 1985; Iaccarino and Salvatorini, 1978; and Cita et al., 1976).

A biometric study comparing Mediterranean and Atlantic forms of $G$. conomiozea and $G$. conoidea with the Pacific ones is in progress (G. G.), in order to clarify if we are dealing with different ecophenotypes of a single species reflecting environmental variations (different water masses) as suggested by Sierro et al. (1987b). The Tyrrhenian forms of the G. miotumida group (sensu Sierro, 1985) are more umbilically inflated, some of them having more chambers (6-7) in the last whorl (G. mediterranea of some authors). In the adjacent part of the Atlantic, these forms occur only sporadically, with less conical forms being dominant. The same trend can also be seen in the unkeeled forms of Globorotalia.

As regards $G$. dalii Perconig, there is a quite unanimous consensus: it is a younger synonym of $G$. miotumida.

\section{ACKNOWLEDGMENTS}

The authors greatly acknowledge K. Kastens and I. Premoli Silva as well as other anonymous reviewers for their constructive criticisms. Thanks are extended to M.J. Urrutiaguer for her help in processing samples for stable isotope analyses. This study was partly founded through INSU-DBT French Project, Italian MPL $40 \%$, and Spanish C.A.1.A.Y.T., PB 85.0315. $\mathrm{CO}_{2.00}$ Project. This is contribution CNRSINSU no. 49 to the DBT French Project "Message sédimentaire."

\section{REFERENCES}

Berggren, W. A., Kent, D. V., and Van Couvering, J. A., 1985. The Neogene: Part I Neogene geochronology and chronostratigraphy. In Snelling, N. J. (Ed.) The chronology of the geological record, Geol Soc. Mem., 10:211-260.

Bossio, A., El Bied Rakich, K., Gianelli, L., Mazzei, R., Russo, A., and Salvatorini, G., 1976. Correlation de quelques sections stratigraphiques du Mio-Pliocéne de la zone atlantique du Maroc avec les stratotypes du Bassin méditerranéen sur la base des foraminiféres planctoniques, nannoplancton calcaire et Ostracodes. Atti. Soc. Tosc. Sc. Nat., Mem., 83:121-137.

Cita, M.B., Colalongo, M.L., d'Onofrio, S., Iaccarino, S., and Salvatorini, G., 1978. Biostratigraphy of deep-sea sediments (Sites 372 and 375) with special reference to the Messinian/ pre-Messinian interval. In Hsü, K. J., Montadert, L., et al., Init. Repts. DSDP, 42, Pt. 1, Washington (U.S. Govt. Printing Office), 671-685.

Cita, M.B., and Ryan, W.B.F., 1978. The Bou Regreg section of the Atlantic coast of Morocco. Evidence, timing and significance of Late Miocene regressive phase. Riv. It. Paleontol., 84:1051-1082.

1979. Late Neogene environmental evolution. In von Rad, U., Ryan, W.B.F., et al., Init. Repts. DSDP, 47, Pt. I, Washington (U.S. Govt. Printing Office), 447-459.

Colalongo, M. L., di Grande, A., D’Onofrio, S., Giannelli, L., Iaccarino, S., Mazzei, R., Romeo, M., and Salvatorini, G., 1979. Stratigraphy of Late Miocene Italian sections straddling the Tortonian/ Messinian boundary. Boll. Soc. Paleontol. It., 18:258-302.

D’Onofrio, S., Gianelli, L., Iaccarino, S., Morlotti, E., Romeo, M., Salvatorini, G., Sampo, M., and Sprovieri, R., 1975. Planktonic foraminifera from some italian sections and the problem of the lower boundary of the Messinian. Boll. Soc. Paleontol. It, 14:177-196.

Feinberg, H., and Lorenz, H. G., 1970. Nouvelles données stratigraphiques sur le Miocéne supérieur et le Pliocéne du Maroc Occidental. Notes Serv. Géol. Maroc, 225:21-26.

Hsü, K. J., 1986. Unresolved problems concerning the Messinian Salinity Crisis. G. Geol., 47:203-212.

Iaccarino, S., 1985. Mediterranean Miocene and Pliocene planktic foraminifera. In Bolli, H. M., Saunders, J. B., and Perch-Nielsen, K. (Eds.) Plankton Stratigraphy. Cambridge (Cambridge Univ. Press), 283-314.

Iaccarino, S. and Salvatorini, G., 1979. Planktonic foraminiferal biostratigraphy of Neogene and Quaternary of Site 398 of DSDP Leg 47B. In Sibuet, J. C., Ryan, W.B.F., 1979. Init. Repts. DSDP, 47, Pt. 2, Washington (U.S. Govt. Printing Office), 255-285.

1982. A framework of planktonic foraminiferal biostratigraphy for Early Miocene to Late Pliocene Mediterranean area. Paleontol. Stratigr. Evol., 2:115-125.

Keigwin, L. D.,1979. Late Cenozoic stable isotope stratigraphy and paleoceanography of DSDP sites from the east equatorial and central North Pacific Ocean. Earth Planet. Sci. Lett., 45:361-382.

Keigwin, L. D., Jr., Aubry, M. P., and Kent, D. V., 1987. Upper Miocene stable isotope stratigraphy and magnetostratigraphy of North Atlantic DSDP Sites. In Ruddiman, W. F., Kidd, R. B., et al. Init. Repts. DSDP, 94, Washington (U.S. Govt. Printing Office), 935963.

Keigwin, T. S., and Shackleton, N. J., 1980. Uppermost Miocene Carbone isotope stratigraphy of a piston core in the Equatorial Pacific. Nature, 284:613-614.

Langereis, C. G., Zachariasse, W. J., and Zijderveld, J.D.A., 1983. Late Miocene magnetostratigraphy of Crete, Mar. Micropaleontol., 8: 261-281. 
Loutit, T. S., and Keigwin, L. D., 1982. Stable isotope evidence for latest Miocene sea-level fall in the Mediterranean region. Nature, 300: 163-166.

Loutit, T. S., and Kennett, J. P., 1979. Application of carbon isotope stratigraphy to Late Miocene shallow marine sediments. New-Zealand Sci., 204:392-397.

McKenzie, J. A., and Oberhänsli, H., 1985. Paleoceanographic expression of the Messinian salinity crisis. In Hsü, K. J., and Weissert, H. S. (Eds.), South Atlantic Paleoceanography: Cambridge (Cambridge Univ. Press), 99-123.

McKenzie, J. A., Weissert, H. J., Poore, R. Z., Wright, R. C., Percival, S. F., Jr, et al., 1984. Paleoceanographic implications of stable isotope data from upper Miocene-lower Pliocene sediments from the southeast Atlantic (Deep Sea Drilling Project Site 519). In Hsü, K. J., LaBrecque, J. L., et al., Init. Repts. DSDP 73: Washington (U.S. Govt. Printing Office), 717-784.

Montenat, C., Bizon, G., and Bizon, J.-J, 1975. Remarques sur le forage Joides 121 en Mer d'Alboran (Méditerranée occidentale). Bull. Soc. Géol. Fr., 7:45-51.

Muller, D. W., in press. Event Stratigraphy and paleoceanography in the Fortuna and Sorbas Basin (SE Spain): a scenario for the Messinian salinity crisis.

Ricci Lucchi, F., Colalongo, M. L., Cremoni, G., Gasperi, G., Iaccarino, S., Papani, G., Raffi, S., and Rio, D., 1982. Evoluzione sedimentaria e paleogeografica nel margine appenninico. In Cremoni, G., and Ricci Lucchi, F., (Eds.) Guida a la geologia italiana, 17-46.

Rutford, R. H., Craddock, C., White, C. M., and Armstrong, R. L., 1972. Tertiary glaciation in the Jones Mountains. In, Adie, R. I. (Ed.). Antarctic geology and geophysics, Oslo, Universitetsforlaget, 239-250.

Salvatorini, G., and Cita, M. B., 1979. Miocene foraminiferal biostratigraphy, DSDP Site 397 (Cap Bojador, North Atlantic): In von Rad, U., Ryan, W. B. F., et al., Init, Repts. DSDP, 47, 1, Washington (U.S. Govt. Printing Office), 317-373.

Scott, G. H., 1980. Upper Miocene biostratigraphy: Does Globorotalia conomiozea occur in the Messinian? Rev. Esp. Micropaleontol., 12: 489-537.

Shackleton, N. J., Hall, M. A., and Boersma, A., 1984. Oxygen and carbon isotope data from Leg 74 foraminifers. In Moore, T. C., Jr, Rabinowitz, P. D., et al. Init. Repts. DSDP, 74: Washington (U.S. Govt. Printing Office), 599-661.

Shackleton, N. J., and Kennett, J. P., 1975a. Late Cenozoic oxygen and carbon isotopic changes at DSDP Site 284: Implications for glacial history of the Northern Hemisphere and Antarctica. In Kennett, J. P., Houtz, R. E., et al., Init. Repts. DSDP, 29: Washington (U.S. Govt. Printing Office), 801-817.

1975b. Paleotemperature history of the Cenozoic and the initiation of Antarctic glaciation: oxygen and carbon isotope analyses in DSDP Sites 277, 279, 281. In Kennett, J. P., Houtz, R. E., et al. Init. Repts. DSDP, 29: Washington (U.S. Govt. Printing Office), 743-756.
Shipboard Scientific Party, 1987. Site 654. In Kastens, K. A., Mascle, J., et al., Proc. ODP, Init. Repts, 107: College Station, TX (Ocean Drilling Program), 747-875.

Sierro, F. J., 1984. Foraminiferos planctonicos y bioestratigrafia del Mioceno superior-Plioceno del borde occidental de la Cuenca del Guadalquivir. (S.o. de Espana). [Ph.D. dissert.] Univ. Salamanca. 1985. The replacement of the "Globorotalia menardii" group by the "Globorotalia miotumida": an aid to recognize the Tortonian-Messinian boundary in the Mediterranean and the adjacent Atlantic. Mar. Micropaleontol., 9:525-535

1987a. Foraminiferos planctonicos del Néogéno marino del sector occidental de la Cuenca del Guadalquivir: sintesis y principales resultados Paleontologia del Neógeno de Huelva, Departemento de Paleontologia de la Universidad de Salamanca. Ediciones Universidad de Salamanca: 23-54.

in press. Variations in the assemblage of keeled Globorotalids of the N.E. Atlantic and Mediterranean during the Upper Miocene.

Sierro, F. J., Flores, J. A., Civis, J., and Gonzalez-Delgado, J. A., 1987b. New criteria for the correlation of the Andalusian and Messinian stages. Proceed. VIIIth Congress Reg. Medit. Neog. Strat. Budapest Sept. 1985. Ann. Inst. Geol. Publ. Hungar. LXX: 355-361.

Tjalsma, R. C., 1971. Stratigraphy and foraminifera of the Neogene of the Eastern Guadalquivir (Southern Spain). Utrecht Micropaleontol. Bull., 4:1- 161 .

Vergnaud Grazzini, C., 1978. Miocene and Pliocene oxygen and carbon isotopic changes at DSDP Sites 372, 374 and 375: implications for pre-Messinian history of the Mediterranean. In Hsü, K. J., Montadert, L., et al., Init. Repts. DSDP, 42: Washington (U.S. Govt. Printing Office), 829-836.

Vincent, E., Killingley, J. S., and Berger, W. H.,1980. The magnetic epoch-6 carbon shift: A change in the ocean's ${ }^{13} \mathrm{C} /{ }^{12} \mathrm{C}$ ratio 6.2 million years ago. Mar. Micropaleontol., 5:185-203.

Wernli, R., 1977. Le Messinien a Globorotalia conomiozea foraminifére planctonique de la cỡe méditerranéenne). Eclogae Geol. Helv., 73: 71-93.

Zachariasse, W. J., 1975. Planktonic foraminiferal biozonation of the late Neogene of Crete (Greece). Utrecht Micropaleontol. Bull, 11:1171

1979a. Planktonic foraminifera from Potamidha 1: taxonomic and phyletic aspects of keeled globorotaliids and some environmental estimates. Utrecht Micropaleontol. Bull., 21:129-166.

$1979 \mathrm{~b}$. The origin of Globorotalia conomiozea in the Mediterranean and the value of its entry level in biostratgraphic correlations. Ann. Geol. Pays Hellen., Tome hors série, fasc. III:12811292. VIIth International Congress on Mediterranean Neogene, Athens, 1979.

Date of initial receipt: 2 May 1988

Date of acceptance: 8 March 1989

Ms 107B-157 